\title{
Troska o zachowanie kultury narodowej przez polskie rodziny migracyjne i instytucje edukacyjne na przykładzie działalności polskich szkół w Leuven
}

W Europie, która powstawała i zmieniała się pod wpływem różnych grup etnicznych, kulturowych i religijnych, nie brakuje przykładów ruchów migracyjnych i stopniowego wrastania migrantów w jej rzeczywistość społeczno-kulturową. Jednocześnie wielu Europejczyków szukało swojego miejsca, wyjeżdżając do Australii, Ameryki Północnej i Południowej. Podobnie patrząc na dzieje Polski, można wskazać z jednej strony na ruchy migracyjne i przybywanie do naszego kraju migrantów, zwłaszcza z przyczyn politycznych i religijnych, jak również można podać wiele przykładów emigracji rodaków zarówno z powodów politycznych, jak i ekonomicznych. Polacy opuszczali ojczyznę, udając się głównie do Europy Zachodniej, Ameryki Północnej i Południowej ${ }^{1}$. Uciekali przed prześladowaniami politycznymi, marginalizacją, szukali lepszej sytuacji życiowej, zawodowej, naukowej oraz

1 Por. I. E. Waldzińska, Specyfika migracji rodzin polskich w kontekście integracji z Unią Europejską, w: Nauki o rodzinie w służbie rodziny, red. J. Stala, Kraków 2014, s. 483. 
przestrzeni rozwoju i wolności. Motywem migracji były zarówno zła sytuacja ekonomiczna czy polityczna, jak i nowe możliwości, w tym intensywny rozwój przemysłu niosący zapotrzebowanie na siłę roboczą w krajach wyjazdu². Po II wojnie światowej wielu Polaków doświadczyło ruchów migracyjnych: najpierw z powodu przesunięcia granic Polski i włączenia terenów na wschodzie kraju do ZSRR, co wiązało się z procesem zasiedlania ziem zachodnich, później w 1968 roku, kiedy Polacy pochodzenia żydowskiego zostali zobligowani do wyjazdu do Izraela, wreszcie w latach 80 . XX wieku, gdy wiele osób zaangażowanych w ruch solidarnościowy opuściło Polskę ze względów politycznych ${ }^{3}$. Później, po podpisaniu umów bilateralnych Polski z Belgią, Francją, Hiszpanią, Luksemburgiem i Niemcami, wielu Polaków podjęło pracę poza granicami ojczyzny w rolnictwie, ogrodnictwie, usługach; wyjechało na staże zawodowe, zostało delegowanych w ramach swoich kontraktów, lub zatrudnionych jako pracownicy deficytowych specjalności, a najmłodsi podjęli pracę jako au pair ${ }^{4}$. Największą zmianę przyniósł rok 2004, kiedy Polska stała się członkiem Unii Europejskiej i po otwarciu rynków pracy przez niektóre kraje Europy Zachodniej mieszkańcy naszego kraju zaczęli szukać zatrudnienia i rozwoju w Unii Europejskiej, czemu sprzyja duża różnica płac między Polską a tymi krajami Europy, a także wysoki współczynnik bezrobocia w ojczyźnie ${ }^{5}$.

\section{Wybrane konsekwencje migracji rodzin}

Migracja jest zawsze wyzwaniem zarówno osobistym, jak i rodzinnym i społecznym, niosącym szansę rozwoju, ale i zagrożenia. Konsekwencje migracji dotyczą nie tylko osób wyjeżdżających, ale również ich rodzin. Wraz z nowymi szansami przynoszą trudności, ryzyko, niebezpieczeństwa

2 Por. S. Kozak, Patologia eurosieroctwa w Polsce. Skutki migracji zarobkowej dla dzieci i ich rodzin, Warszawa 2010.

3 Por. W. Danilewicz, Społeczne konsekwencje migracji zagranicznych, w: Migracja, uchodźstwo, wielokulturowość. Zderzenie kultur we współczesnym świecie, red. D. Lalak, Warszawa 2007, s. 153; I. E. Waldzińska, Specyfika migracji rodzin polskich w kontekście integracji $z$ Unia Europejską, dz. cyt., s. 492-493.

4 Por. J. Wiśniewski, M. Duszczyk, Emigrować i wracać. Migracje zarobkowe Polaków po 1 maja 2004, Warszawa 2006.

5 Por. I. E. Waldzińska, Specyfika migracji rodzin polskich w kontekście integracji $z$ Unią Europejską, dz. cyt., s. 492-493. 
i zagrożenia dla stabilności i prawidłowego funkcjonowania rodziny. Jednak przede wszystkim przebywanie w nowym kulturowo środowisku niesie zagrożenie zagubienia wzorów kulturowych i osłabienia lub utraty języka ojczyzny pochodzenia.

Należy zaznaczyć, że współcześnie coraz powszechniejszym zjawiskiem stają się grupowe migracje rodzin, co powoduje powstanie sieci migracyjnych, w których kolejne osoby dołączają do członków rodzin już przebywających za granicą. Zazwyczaj na końcu przybywają do rodziny jej najmłodsi członkowie. Bezpośrednią konsekwencją migracji dwóch pokoleń jest ograniczenie kontaktów dzieci z najstarszym pokoleniem - dziadkami oraz dalszymi krewnymi, którzy pozostali w ojczyźnie. Sytuacja ta zmienia historycznie uformowany w Polsce model rodziny wielopokoleniowej, w której wpływ na rozwój, wychowanie i uspołecznienie najmłodszego pokolenia mają nie tylko rodzice, ale też dziadkowie. Brak bezpośrednich kontaktów prowadzi do zachwiania więzi między pokoleniami, co zaburza lub wręcz uniemożliwia przekazanie wnukom wzorców postępowania, norm, wartości, tradycji rodzinnych, zwyczajów, a nawet historii rodzinnych. W sytuacji migracji rodziny dwupokoleniowej proces wychowania dziecka i jego wdrażania do kultury dokonuje się w nowej sytuacji społecznej, kulturowej, religijnej ${ }^{6}$. Konsekwencje migracji młodszych pokoleń boleśnie wpływają także na najstarsze pokolenia pozostające w kraju pochodzenia. Babcie i dziadkowie zachowują często kontakt telefoniczny, ale nie uczestniczą bezpośrednio w życiu dzieci i wnuków, nie rozumieją nowych uwarunkowań, czują się zagubieni i niepotrzebni. Z powodu osłabionych kontaktów, zachwianej więzi międzypokoleniowej oraz braku bezpośredniego uczestnictwa dziadków w życiu najmłodszego pokolenia pojawia się zagrożenie utraty w najmłodszym pokoleniu polskich wzorów kulturowych oraz języka polskiego ${ }^{7}$.

$\mathrm{W}$ procesie przystosowania się rodziny do życia w nowej kulturze lub funkcjonowania w obydwu kulturach czy na granicy dwóch różnych kultur można także wyróżnić następujące formy: asymilacji, integracji, separacji, marginalizacji ${ }^{8}$. Asymilacja oznacza, że członkowie rodziny całkowicie

\footnotetext{
$6 \quad$ Por. W. Danilewicz, Społeczne konsekwencje migracji zagranicznych, dz. cyt., s. 163164.

Por. W. Danilewicz, Społeczne konsekwencje migracji zagranicznych, dz. cyt., s. 164.

Por. K. Szyniszewska, $W$ poszukiwaniu swojej tożsamości - drugie pokolenie migrantów. Na przykładzie Francji i USA, w: Migracja, uchodźstwo, wielokulturowość..., dz. cyt., s. 248.
} 
upodobniają się do nowej kultury miejsca zamieszkania. Wówczas migranci łatwiej uczestniczą w kulturze otoczenia i nie dochodzi do konfliktów ze społecznością przyjmującą. Jednocześnie zazwyczaj to młodsze pokolenie szybciej przyjmuje nowe wzorce kulturowe, co prowadzi do konfliktów ze starszym i najstarszym pokoleniem ${ }^{9}$. Z kolei integracja występuje, kiedy członkowie rodziny zachowują kulturę kraju pochodzenia, a jednocześnie starają się zrozumieć i przyjąć nową kulturę ${ }^{10}$. Często rodziny, integrując się z nową kulturą, zachowują pewne elementy starej, zwłaszcza najmocniej zakorzenione lub pasujące do nowej rzeczywistości, a z nowej kultury także przyjmują elementy zbliżone do dotychczasowej kultury. W sytuacji kiedy kultura kraju lub regionu nowego miejsca zamieszkania rodziny migracyjnej bardzo różni się od dotychczasowej, ujawnia się separacja kulturowa. Dorośli członkowie rodziny współpracują z przedstawicielami innej kultury w kwestiach zawodowych, ale zachowują i świadomie pielęgnują swoją odrębność kulturową. Natomiast marginalizacja kulturowa oznacza odrzucenie przez rodzinę migracyjną kultury kraju pochodzenia, ale również odsunięcie lub niechęć wobec nowej. W tej sytuacji ujawniają się mocne bariery kulturowe, komunikacyjne i społeczne ${ }^{11}$.

Obszar uwarunkowań kulturowych stanowi dla całej rodziny, a szczególnie dla dzieci i młodzieży, punkt odniesienia, perspektywę, z której oceniają otaczającą rzeczywistość. Zamknięcie kulturowe izoluje dziecko i przyczynia się do rozwoju postaw aspołecznych, z kolei nadmierna otwartość i podziw dla nowej kultury niosą zagrożenie odrzucenia kultury kraju pochodzenia.

\section{Polskie szkoły w kontekście kulturowym Flandrii}

Wyjeżdżając w poszukiwaniu nowych miejsc życia i rozwoju, Polacy często wybierają kraje zbliżone kulturowo do Polski, gdzie łatwiej mogą dokonać asymilacji lub integracji kulturowej. Innym niewątpliwie ważnym

9 Por. B. Rożnowski, D. Bryk, Stres emigracji zarobkowej i jego konsekwencje dla systemu wartości migrantów, w: Migracja - wyzwanie dla XXI wieku, red. M. S. Zięba, Lublin 2008, s. 152.

10 Por. K. Szyniszewska W poszukiwaniu swojej tożsamości - drugie pokolenie..., dz. cyt., s. 248.

11 Por. H. Grzymała-Moszczyńska, Uchodźcy, Kraków 2000, s. 19. 
czynnikiem jest język, stąd dominacja wyjazdów do krajów anglojęzycznych, gdzie szybciej, sprawniej i bardziej efektywnie mogą się porozumieć.

Wprawdzie w Belgii język angielski nie jest językiem urzędowym, ale Flamandowie słyną z dobrej znajomości języków obcych, w tym angielskiego, stąd niewielka Belgia, tworząca wraz z Holandią i Luksemburgiem grupę Beneluksu, staje się jednym z ważnych krajów migracyjnych Polaków. $\mathrm{Na}$ terenie Belgii obowiązują trzy języki urzędowe: niderlandzki (dokładniej dialekt flamandzki), francuski i niemiecki. Dlatego dzieci z polskich lub mieszanych rodzin przebywające w Belgii w zależności od miejsca zamieszkania częściej uczą się języka flamandzkiego (północna część kraju), francuskiego na południu i niemieckiego w enklawie na wschodzie Belgii. Obecność aż trzech języków oficjalnych motywuje polskie dzieci do szybszej nauki języków obcych.

Leuven jest znanym miastem akademickim, w którym znajduje się jeden z najstarszych uniwersytetów w Europie, założony w 1425 roku Katolicki Uniwersytet $w$ Leuven (Katholieke Universiteit Leuven), znajdujący się w dziesiątce najlepszych światowych uczelni. Zajęcia dydaktyczne w KU Leuven odbywają się w języku flamandzkim i angielskim, ze względu na duże grupy studentów język angielski jest w tym mieście bardzo rozpowszechniony. To niewątpliwie ułatwia migrantom z Polski sprawniejsze przystosowanie się do nowej sytuacji społeczno-kulturowej.

$\mathrm{Na}$ terenie miasta działają dwie polskie placówki edukacyjne: Centrum Kultury i Języka Polskiego w Leuven - Daskalia ${ }^{12}$ oraz Polska Szkoła i Przedszkole im. Wisławy Szymborskiej ${ }^{13}$. Są to równorzędne organizacje prowadzące edukację w języku polskim. Polskie szkoły dbają o nabywanie przez uczniów umiejętności posługiwania się językiem ojczystym, utrwalają tradycje i formują tożsamość polską. Obie szkoły powołali do istnienia Polacy, którzy mimo przebywania na obczyźnie nie zapominają o kraju, ale troskliwie pielęgnują miłość do ojczyzny i budują silne więzi z krajem pochodzenia. Polska Szkoła w Leuven Mała Daskalia funkcjonuje od roku 2013 i oferuje dzieciom zarówno zajęcia dydaktyczne z języka polskiego z elementami historii i geografii Polski, jak i również wiele zajęć fakultatywnych: katechezę, rytmikę, język francuski, język angielski, biologię, chemię, fizykę, gimnastykę korekcyjną, zajęcia teatralne ${ }^{14}$. Z kolei Polska Szkoła

\footnotetext{
12 Por. Polska szkoła w Leuven, http://daskalia.eu/polska-szkola-w-leuven/ (01.12.2018).

13 Por. Witamy!, http://polskaszkolaleuven.eu/ (01.12.2018).

14 Por. Polska szkoła w Leuven, http://daskalia.eu/polska-szkola-w-leuven/ (01.12.2018).
} 
i Przedszkole im. Wisławy Szymborskiej w Leuven działają od 2017 roku. Zostały zorganizowane przez obecną dyrektor szkoły Elżbietą Grabiec, dyrektor przedszkola Elżbietą Czarnecką oraz psychologa szkolnego Joannę Kądzielaw-Follon. Szkoła, biorąc pod uwagę potrzeby polskich rodziców mieszkających w Leuven i okolicach, podjęła wyzwanie stałej edukacji dzieci, które posługują się językiem polskim w rodzinach, ale potrzebują doskonalenia umiejętności językowych w trzech obszarach: pisania, czytania oraz zdobywania specjalistycznego słownictwa. Dodatkowo dzięki obecności rówieśników dzieci mogą ćwiczyć umiejętności językowe, stosując codzienny język polski, zwłaszcza że dzieci korzystają z różnych języków obcych, zatem język polski staje się podstawowym środkiem komunikacji15. Polska Szkoła i Przedszkole im. Wisławy Szymborskiej wskazują, że nie chcą działać tylko w zakresie doskonalenia umiejętności językowych, ale pragną „przekazać dzieciom podstawowe wiadomości na temat języka, kultury i tradycji Polski oraz zainteresować je historią, muzyką, literaturą. Chcemy, by pokolenie młodych Polaków na emigracji znało swoje korzenie i było dumne ze swojej dwujęzyczności!"16 Szkoła proponuje zarówno zajęcia dla dzieci przedszkolnych, jak i dzieci uczęszczających do szkoły podstawowej. Głównym celem szkoły jest tworzenie środowiska otwartego na potrzeby dzieci, wspierającego rodziców w procesie formowania tożsamości narodowej potomstwa, wzmacniającego korzenie polskiej kultury oraz przypominającego historię ojczyzny ${ }^{17}$.

Rozwój języka u dzieci jest związany z podstawowymi prawami i zasadami, zależy od rozwoju biologicznego obejmującego uwagę, wzrok, słuch, pamięć, wszelkie umiejętności poznawcze, rozwój motoryczny, zależny od wpływu środowiska. W procesie tym można wyodrębnić poszczególne fazy, między którymi nie istnieją zresztą wyraźne granice. Najważniejszy jest wczesny okres życia, nigdy później nauka języka obcego nie przychodzi tak łatwo jak w dzieciństwie. Dlatego obydwie instytucje zorganizowały także odziały przedszkolne, by najmłodsze pokolenie mogło wzrastać od pierwszych lat w kręgu kultury polskiej. Dlatego w przedszkolu ważne jest respektowanie praw dziecka, wspieranie rozwoju polskości, przekazywanie

15 Por. B. Hałacińska, Wychowanie dzieci dwujęzycznych na przykładzie działalności Polskiej Szkoły w Leuven im. Wisławy Szymborskiej (mps), Tarnów 2018, s. 22-25.

16 Por. Witamy!, http://polskaszkolaleuven.eu/ (10.12.2018).

17 Por. Polska Szkoła w Leuven, http://polskaszkolaleuven.eu/pagina-2/test-1/ (10.12. 2018). 
wartości społecznych i moralnych, motywowanie dzieci do opowiedzenia się za przynależnością do kraju pochodzenia, zachowanie dumy z faktu bycia Polakiem, stałe przybliżanie kultury i tradycji polskich ${ }^{18}$.

Zajęcia dydaktyczne realizowane w szkole i w przedszkolu są przygotowane na podstawie autorskich programów. Polska szkoła i przedszkole im. Wisławy Szymborskiej przyjmuje dzieci od 3 do 12 roku życia z Leuven i okolic oraz z Brukseli. Ze względu na fakt, że dzieci w instytucjach publicznych posługują się językiem flamandzkim albo francuskim, język polski staje się wspólnym językiem codziennej komunikacji1 ${ }^{19}$. Poza zajęciami obowiązkowymi (w klasach 1-3 zajęcia z edukacji wczesnoszkolnej $\mathrm{z}$ wyłączeniem matematyki) oraz w klasach starszych (język polski, historia, geografia, fizyka, matematyka) instytucja proponuje zajęcia dodatkowe realizowane w języku polskim: zajęcia artystyczne, warsztaty fotograficzne, plastyczne, katechezę z przygotowaniem do I Komunii Świętej. Podczas wakacji i ferii prowadzone są także półkolonie, na których uczniowie mogą poznawać zwyczaje, tradycje, normy i inne elementy kultury polskiej, doskonalić swoje umiejętności językowe poprzez zajęcia połączone z zabawą.

\section{Język i kultura}

Skuteczne wypełnienie wskazanych zadań dydaktyczno-wychowawczych polskich szkół w Leuven jest szczególnie ważne w kontekście szybkich przeobrażeń społeczno-kulturowych, na które młode pokolenia Polaków wyrastających poza granicami Polski są szczególnie wrażliwe. Wdrażanie do kultury narodowej połączone $\mathrm{z}$ wychowaniem patriotycznym może stanowić skuteczną pomoc. Celem takiego wychowania jest obudzenie miłości do kraju ojczystego i jego dziedzictwa, zarówno w odniesieniu do przeszłości, teraźniejszości, jak również odpowiedzialności za jego przyszłość i formowanie postawy bezinteresownego działania dla wspólnego dobra ojczyzny ${ }^{20}$. W procesie nauczania i wychowania młodego pokolenia poza ojczyzną polskie szkoły starają się nie tylko nauczyć języka polskiego, prze-

18 Por. Wizja, http://polskaszkolaleuven.eu/przedszkole/wizja/ (01.12.2018).

19 Por. B. Hałacińska, Wychowanie dzieci dwujęzycznych na przykładzie działalności Polskiej Szkoły w Leuven im. Wisławy Szymborskiej, dz. cyt., s. 22-25.

20 Por. M. Łobocki, Teoria wychowania w zarysie, Kraków 2004, s. 288. 
kazać wiedzę o ojczyźnie, ale jednocześnie przedstawiać bogactwo kultury ojczystej, całokształt materialnego i duchowego dorobku Polaków. Pamiętają również o ukazywaniu piękna ojczyzny pod względem geograficznym i krajobrazowym. Wiele dzieci uczęszczających do polskich szkół urodziło się w Polsce i wyjechało wraz z rodzicami do Belgii, ale część z nich urodziła się już w nowym miejscu i zna Polskę głównie z opowiadań rodziców lub dziadków, filmów, książek albo krótkich wakacji spędzanych w Polsce. W tym kontekście niezwykle ważne jest przedstawianie ojczyzny jako wartości, jako czegoś cennego, rzeczywistości, z której młode pokolenie może być dumne, z którą chce się utożsamiać i z którą czuje się emocjonalnie związane mimo przestrzennego rozdzielania ${ }^{21}$.

Mieszkając poza granicami Polski, młodzi ludzie są często przygotowywani do stawania się Europejczykami, którzy odnajdują się we wspólnocie krajów Unii Europejskiej. Jednak udział w tworzeniu większej rzeczywistości wymaga najpierw budowania własnej tożsamości narodowej, formowania postawy szacunku wobec własnego narodu, ojczyzny i kultury. Przypominał o tym w swoich spotkaniach z rodakami papież Jan Paweł II, podkreślając, że jest synem swego narodu: „noszę w sobie całe dziedzictwo jego kultury, jego historii, dziedzictwo zwycięstw..., ale także dziedzictwo klęsk. Noszę w sobie świadomość jego zaniedbań, grzechów i win, ale także świadomość dziejowych krzywd, jakich doznawał, zwłaszcza w ciągu ostatnich dwu stuleci. Jestem synem tego narodu - i dlatego odczuwam głęboko wszystkie, wszystkie jego szlachetne dążenia, pragnienie życia w prawdzie, wolności, sprawiedliwości, solidarności społecznej - pragnienie życia swym własnym życiem. Przecież po tysiącu lat dziejowych doświadczeń ten naród ma swoje własne życie, swą kulturę, swe społeczne tradycje, swoją duchową tożsamość"22.

Słowa papieża z jednej strony podkreślają ogromną wartość narodu, jego historii, dziedzictwa kulturowego oraz znaczenie tożsamości kulturowej, z drugiej wzywają do szacunku względem dziedzictwa narodowego i formowania postawy odpowiedzialności za kulturę narodu. Analiza sytuacji polskich rodzin migracyjnych we Flandrii pokazuje, że zależy im na zacho-

21 Por. J. Wagner, Ojczyzna, w: Słownik katolickiej nauki społecznej, red. W. Piwowarski, Warszawa 1993, s. 117-118.

22 Jan Paweł II, Apel Jasnogórski, II Pielgrzymka do Ojczyzny, 1983, http://www. nauczaniejp2.pl/dokumenty/wyswietl/id/832/pos/6/haslo/dziedzictwo\%20kultury (01.12.2018). 
waniu bogactwa kultury narodowej, w tym języka polskiego, oraz formowaniu postawy szacunku wobec bohaterskich Polaków.

Kultura danego narodu obejmuje swoim zasięgiem naukę, sztukę, ale także moralność i wynikające z niej obyczaje, tradycje narodowe i religij$\mathrm{ne}^{23}$. Dlatego polskie szkoły w Leuven skupiają się nie tylko na przekazywaniu wiedzy na temat ojczyzny, ale także na podsycaniu i pielęgnowaniu więzi z ojczyzną. Organizują spotkania, koncerty, spektakle teatralne przypominające ważne dzieła kultury narodowej. Organizują spotkania z okazji uroczystości religijnych i świąt narodowych, prezentując zwyczaje, tradycje i ucząc młode pokolenia działań związanych z ich przeżywaniem (np. kartki dla Biało-Czerwonej, Dzień Polonii i Flagi RP, jasełka, kiermasz bożonarodzeniowy, zabawy karnawałowe). Dodatkowo szkoły organizują konkursy i przygotowują dzieci do konkursów, np. „Być Polakiem”, „Dyktando polonijne”, „Drogi do wolności”, „Dumni z bycia Polakami”, dzięki którym najmłodsze pokolenie może przeżywać wartość ojczyzny, narodu, języka, symboli i tradycji narodowych.

Obydwie instytucje promują również rozwój kulturalny dorosłych, zapraszając ich na wykłady, warsztaty, koncerty, przedstawienia teatralne, wspólne śpiewanie itp. Szeroko rozumiana kultura pozostaje zawsze dobrem Polaków mieszkających poza granicami ojczyzny. Pamiętają, że naród polski, mimo utraty niepodległości na ponad sto lat, jednak przetrwał, ponieważ zachował, rozwijał i ubogacał swoją kulturę. Dlatego duże znaczenie mają organizowane w szkołach obchody uroczystości narodowych i religijnych pozwalające Polakom mieszkającym w Belgii zaprezentować swoją kulturę Flamandom i Walonom ${ }^{24}$.

* $\quad$ *

Wrastanie dziecka w kulturę narodu polskiego i nabywanie kompetencji kulturowej (umiejętności zachowania się zgodnie z przyjętymi w danej kulturze wzorami), kiedy wraz z rodziną przebywa poza granicami Polski,

\footnotetext{
23 Por. M. Łobocki, Teoria wychowania w zarysie, dz. cyt., s. 290.

24 Por. Aktualności, http://daskalia.eu (12.12.2018); Wizja, http://polskaszkolaleuven. eu/ (12.12.2018); B. Hałacińska, Wychowanie dzieci dwujęzycznych na przykładzie działalności Polskiej Szkoły w Leuven im. Wisławy Szymborskiej, dz. cyt.
} 
jest procesem trudnym, ale jak wskazuje niniejszy artykuł, możliwym do realizacji przy założeniu dobrej współpracy rodziny i szkoły. Polskie rodziny mieszkające w Leuven, Brukseli i okolicach mają nadal poczucie wspólnoty $\mathrm{z}$ narodem polskim, którego kultura jest przez nich traktowana jako cenne dobro, z którego wyrasta jego przeszłość, teraźniejszość i przyszłość Polaków. Kochając własną ojczyznę, jej dzieje i kulturę, dbają wspólnie z polskimi szkołami w Leuven, by obudzić miłość do Polski w najmłodszym pokoleniu i by stopniowo stawało się ono nosicielem kultury narodowej.

\section{Bibliografia}

Aktualności, http://daskalia.eu (12.12.2018).

Grzymała-Moszczyńska H., Uchodźcy, Kraków 2000.

Hałacińska B., Wychowanie dzieci dwujezycznych na przykładzie działalności Polskiej Szkoły w Leuven im. Wisławy Szymborskiej (mps), Tarnów 2018.

Jan Paweł II, Apel Jasnogórski, II Pielgrzymka do Ojczyzny, 1983, http:// www.nauczaniejp2.pl/dokumenty/wyswietl/id/832/pos/6/haslo/dziedzictwo\%20kultury (01.12.2018).

Kozak S., Patologia eurosieroctwa w Polsce Skutki migracji zarobkowej dla dzieci i ich rodzin, Warszawa 2010.

Łobocki M., Teoria wychowania w zarysie, Kraków 2004.

Migracja - wyzwanie dla XXI wieku, red. M. S. Zięba, Lublin 2008.

Migracja, uchodźstwo, wielokulturowość Zderzenie kultur we wspótczesnym świecie, red. D. Lalak, Warszawa 2007.

Nauki o rodzinie w stużbie rodziny, red. J. Stala, Kraków 2014.

Polska szkoła w Leuven, http://daskalia.eu/polska-szkola-w-leuven/ (01.12. 2018).

Wagner J., Ojczyzna, w: Słownik katolickiej nauki społecznej, red. W. Piwowarski, Warszawa 1993, s. 117-118.

Wiśniewski J., Duszczyk M., Emigrować i wracać. Migracje zarobkowe Polaków po 1 maja 2004, Warszawa 2006.

Witamy!, http://polskaszkolaleuven.eu/ (01.12.2018).

Wizja, http://polskaszkolaleuven.eu/ (12.12.2018).

Wizja, http://polskaszkolaleuven.eu/przedszkole/wizja/ (01.12.2018). 